\title{
An Experimental Study on English Listening Class: A Perspective of Cultural Recognition
}

\author{
Qi Qian \\ LiRen College of Yanshan University; QinHuangdao, HeBei, 066004,China \\ 59624917@163.com
}

Keywords: Experimental Study, English Listening, Cultural Recognition

\begin{abstract}
Many researches have demonstrated that cultural recognition can influence the foreign language learning. The study is designed to testify to the effectiveness of development of cultural recognition of college students' listening competence. And the study can give us some messages to improve the English teaching. So the thesis is divided into four chapters. The first chapter is a literature review which summarizes and discusses the main theories about cultural recognition from scholars at home and overseas. The second character is split into research hypothesis and data collection procedures to express the objectives and methodology. The third character mainly expresses the data and makes data analysis. The thesis gives some conclusion about cultural recognition and college students' listening competent in the fourth character.
\end{abstract}

\section{Literature Review}

As far as cultural recognition is concerned, Lessard-Clouston (1997) notes, in the past, people learned a foreign language to study its literature, and this was the main medium of culture. "It was through reading that students learned of the civilization associated with the target language" (Flewelling, 1993: 339, cited in Lessard-Clouston, 1997). In the 1960s and 1970s, such eminent scholars as Hall (1959), Nostrand (1974), Seelve ([1974] 1984), and Brooks (1975) made an endeavour to base foreign language learning on a universal ground of emotional and physical needs, so that 'the foreign culture would appear less threatening and more accessible to the language learner. (Kramsch, 1993: 224). In the heyday of the audiolingual era in language teaching, Brooks (1968) emphasized the importance of culture not for the study of literature but for language learning, as Seelve (1989: 155) has observed. Admittedly, the main thrust of his work was to make people aware that culture resides in the very fabric of their lives - their modus vivendi, their beliefs, assumptions, and attitudes - rather than in a preoccupation with aesthetic reflections or high-falutin ideas.

According to Vygotsky, who was born in 1896, interactions with adults and peers, as well as instruction, are essential for cognitive development. This view was deeply influenced by the Marxist ideas which prevailed in the Soviet Union at the time (the 1930s) of Vygotsky's main psychological writings.

In general, Vygotsky opposed Piaget's image of human development as a lone venture in the world. For Vygotsky, the major task of a theory of development is to understand how cultural tools are acquired by the child. He argued that concepts, language, voluntary attention and memory are functions which originate in culture (i.e. in the interaction between people) and are acquired through development in the interaction between the child and another person. Each of these functions appears first as an interpersonal process before it appears within the child as an intrapersonal process. To take the hypothetical example given in Richardson (1994): when young children first attend nursery many are highly emotionally motivated.

\section{Research design}

The empirical study is conducted among first year students of non-English major of LiRen college in YanShan University. The students major in natural sciences. There are two classes, one of them is the experimental group and the other is the control group. The development of cultural 
recognition is applied in the experimental group instead of the control group in order to see the different results.

Research Hypothesis. During the experiment, qualitative and quantitative research methods are utilized such as pretest and posttest and classroom observation to realize the objective of the research.

Firstly, students in both the experimental group and the control group have similar ability and background before the test.

Secondly, both the experimental group and the control group share the same class hours, neither share more.

Last but not least, compared to the control group, students' listening competence in the control group is improved by developing of the cultural recognition of the target language, in this case, English.

Data collection procedures. The whole process lasts one school term from March, 7, 2013 to June, 20, 2014. The test include two sets: pre-test and post-test. At the beginning of this term, the researcher operated the pre-test in the experimental group and control group in order to survey the situation of students' listening competence and testify whether the starting points are similar between two groups. After a term of culture teaching in the experimental group, the post-test was tried out at the end of the term so as to see result differences of the two groups, analyze the causes and testify the hypotheses.

\section{Data Analysis and Discussion}

Data analysis. In order to analyze the questionnaire thoroughly we started with the two questions about their interest to learn and use English in their daily life

In the following section we are about to talk about the two sorts of T-tests of the pretest and postest. Table 4.9 is T-test for independent samples before and after the experiment and table 4.10 is T-test for paired samples for both groups.

Table 4.1 T-test for independent samples before and after the experiment

\begin{tabular}{l|l|l|l|l|l}
\hline Type of test & Group & $\begin{array}{l}\text { Number of } \\
\text { students }\end{array}$ & $\begin{array}{l}\text { Medium } \\
\text { value }\end{array}$ & $\begin{array}{l}\text { Standard } \\
\text { deviation }\end{array}$ & Sig.(2-tailed) \\
\hline Pretest & $\begin{array}{l}\text { Experimental } \\
\text { group }\end{array}$ & 63 & 51.0476 & 6.72604 & 0.833 \\
\hline Pretest & $\begin{array}{l}\text { Control } \\
\text { group }\end{array}$ & 69 & 50.7826 & 7.62324 & - \\
\hline Posttest & $\begin{array}{l}\text { Experimental } \\
\text { group }\end{array}$ & 63 & 62.8413 & 8.28564 & 0.000 \\
\hline Posttest & $\begin{array}{l}\text { Control } \\
\text { group }\end{array}$ & 69 & 51.1014 & 7.56568 & - \\
\hline
\end{tabular}

Table 4.2 T-test for paired samples of both groups

\begin{tabular}{l|l|l|l|l}
\hline Group & Type of test & $\begin{array}{l}\text { Number of } \\
\text { students }\end{array}$ & $\begin{array}{l}\text { Medium } \\
\text { value }\end{array}$ & Sig.(2-tailed) \\
\hline $\begin{array}{l}\text { Experimental } \\
\text { group }\end{array}$ & Pretest & 63 & 51.0476 & 0.000 \\
\hline $\begin{array}{l}\text { Experimental } \\
\text { group }\end{array}$ & Posttest & 63 & 62.8413 & - \\
\hline Control group & Pretest & 69 & 50.7826 & 0.814 \\
\hline Control group & Posttest & 69 & 51.1014 & - \\
\hline
\end{tabular}

Table one is the T-test for independent samples---that is 63 students from the experimental group and 69 students from the control group. We can see from the table that before the experiment the medium value of the two groups are 51.0476 and 50.7826 . $\mathrm{P}=0.833>0.05$ indicating that there are not much difference between the performance of the two groups. Table 4.10 is the T-test for 
independent samples after the experiment. The medium value of the experimental group raised to 62.8413, but the control group scores 51.1014, not much progress compared to the statistics we have before the experiment. $(\mathrm{P}=0.000<0.05)$ From the two tables we can see clearly that after sixteen weeks of instruction of the development of the schemata of the target culture the experimental group had achieved apparent improvement in the English listening proficiency. The next two tables are T-test for paired samples, that is to compare the results within the same group before and after the experiment. The table next is the comparison of the experimental group.

Table 4.11 is a comparison of the performance of the students in the experimental group on each section before and after the experiment. As the table shows, the test we have chosen is consisted of four sections. In the first section the correct answer in the pre-test is $43.3 \%$ but after the experiment it has raised to $56.0 \%$. The second section is from $32.7 \%$ to $45.1 \%$. The correct answer in section 3 before the training is $57.3 \%$ and $69.8 \%$ after the training. And in section four $41.4 \%$ of the questions have been answered correctly in comparison to 52.8\% correct answers after the cultivation of the schemata of the target culture.

Table 4.3 Comparison of the performance in the experimental group

\begin{tabular}{|c|c|c|c|}
\hline Secti & Content & $\begin{array}{l}\text { Before the } \\
\text { experiment }\end{array}$ & $\begin{array}{l}\text { After the } \\
\text { experiment }\end{array}$ \\
\hline $\begin{array}{l}\text { Secti } \\
\text { on } 1\end{array}$ & 10 blanks & $43.3 \%$ & $56.0 \%$ \\
\hline on $2^{\text {Secti }}$ & $\begin{array}{l}3 \text { multiples } \\
\text { 4labels 3blanks }\end{array}$ & $32.7 \%$ & $45.1 \%$ \\
\hline $\begin{array}{l}\text { Secti } \\
\text { on } 3\end{array}$ & $\begin{array}{l}4 \text { numbers } 6 \\
\text { blanks }\end{array}$ & $57.3 \%$ & $69.8 \%$ \\
\hline $\begin{array}{l}\text { Secti } \\
\text { on } 4\end{array}$ & $\begin{array}{l}4 \text { multiples } 6 \\
\text { blanks }\end{array}$ & $41.4 \%$ & $52.8 \%$ \\
\hline
\end{tabular}

We can see from the statistics that after a whole semester's training of using schemata and cultivation of the schemata of target culture, in this case the English culture, more and more students have learned to compare what they already have of their native culture schemata and the target culture schemata, and try to be ephthetic in the intercultural communications. For example, in section one, the scene is how to open a bank account. Most of the college students are over 20 years old and have the experience of opening their own bank account. Thus they can understand the process and use their own knowledge and schemata of opening a bank account in the dialogue processing and even try to predict. Another example is section three. It is a students' survey about the different types of music and people's preference of the music. They can easily associate different types of Chinese music with those types of foreign music and then have a comprehension of the information the survey students in the dialogue need to collect. The whole table shows an increase in the correct answers due to the schemata analysis, comparison and formation of the target culture.

\section{Discussion}

Schemata in listening course can be generally categorized into two types: language schemata and knowledge schemata. Language schemata concerning phonological, lexical, syntactic and grammatical knowledge that students are supposed to have grasped in their junior and senior middle school. Knowledge schemata is generally taken from the typical daily life conversations. For instance, conversations happened in hotel, restaurant, post office, hospital, book store, department store, library, bank, airport and so on and so forth. The relationship between the interlocutors and how they conversed under these circumstances are generally fixed, that is to say, there is a fixed 
way how they would behave or communicate with each other in these conversations. Thus, grasping the knowledge of the target culture or better, to form the schemata of the target knowledge would be a neat way to predict their conversations in these situations.

\section{Conclusion}

The development of cultural recognition using skemata does enhance students' listening competence. Students from the experimental group have made greater progress in listening comprehension which means they developed their listening competence more during the semester. Considering the fact that students from the two groups have the same starting point---pretest score and similar background---age, major and propotion of the different genders. The development of cultural recognition using skemata does enhance students' listening competence. Thus the third hypothesis is proved to be correct.

Theoretically, schema of the target culture originates in culture and formed in the development of cognition, therefore, it facilitates the process of cultural recognition. In facing cultural discrepancy, cultural recognition of the target culture and empathy are highlighted in cultural teaching in order to realize intercultural communication competence. It can be realized by schema theory from the aspect of cultural recognition. Through the cultivation of schemata of the target culture, students develop cultural recognition of it gradually. The more they learn about the foreign culture the better they understand the culture and the more complex and detailed their schemata of the target culture can be. After an appropriate amount of time students develop empathy of the target culture, which is they tend to think and behave the way native speakers do. Thus they attain competence to communicate interculturally.

\section{References}

[1] Bennett, M. J. 1997. How Not to Be a Fluent Fool: Understanding the Cultural Dimension of Language. In Alvino E. Fantini (Ed.), New Ways in Teaching Culture. pp. 109-135. Alexandria, VA: Teachers of English to Speakers of Other Languages, Inc.

[2] Brooks, N. 1968. Teaching culture in the foreign language classroom. Foreign Language Annals, 1 (3).

[3] Brown, D. 1993. Principles of Language and Teaching. NY: Prentice Hall.

[4] Byram, M. 1988. Foreign language education and cultural studies. Language, Culture and Curriculum, 1(1), pp.15-31.

[5] Byram, M. 1997. Teaching and Assessing Intercultural Communicative Competence. Clevedon: Muhilingual Matters.

[6] Campbell, D. L. \& J.C, Stanley, 1963. Experimental and quasi-experimental designs for

[7] Research on teaching, In N. L. Gage (ed.), Handbook of Research on Teaching, Rard McNally.

[8] Chen, S. 1998. The Teaching of Culture in Foreign Language Education. Beijing: Beijing language and culture university press.

[9] Crystal, D. 1997. English as a Global Language. New York: Cambridge University Press.

[10] Dai, W. \& F, Wu. 2010. On the development of foreign language studies in China: Constraints and strategies (In Chinese). Foreign Language Teaching and Research 